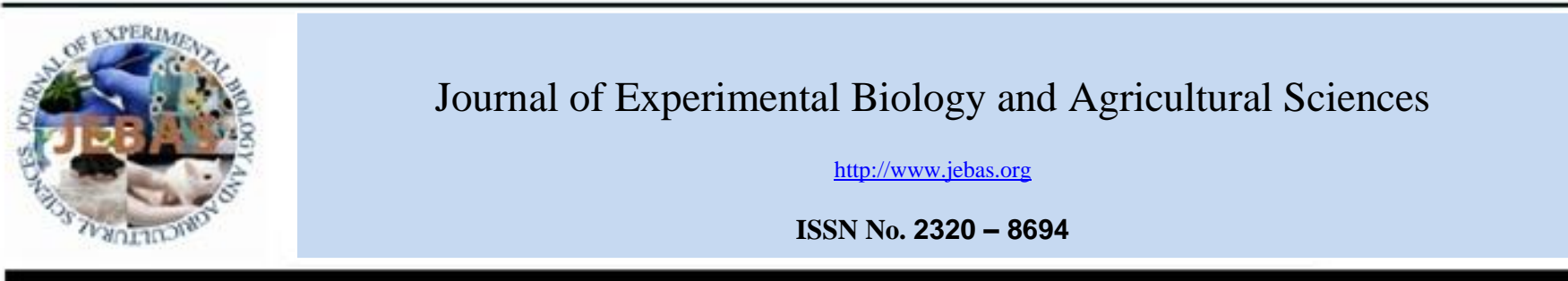

\title{
DETERMINATION OF TOXICITY OF NEWER INSECTICIDE MOLECULES AGAINST PULSE BEETLE, Callosobruchus maculatus (FABRICIUS) (CHRYSOMELIDAE: COLEOPTERA) UNDER LABORATORY CONDITIONS
}

\author{
S Ramesh Babu ${ }^{1 *}$, SVS Raju $^{2}$, PS Singh ${ }^{2}$, Kamal Ravi Sharma ${ }^{1}$
}

${ }^{1}$ Research Scholar, Department of Entomology and Agril. Zoology, Banaras Hindu University, Varanasi, Uttar Pradesh.

${ }^{2}$ Professor, Department of Entomology and Agril. Zoology, Banaras Hindu University, Varanasi, Uttar Pradesh.

Received - November 26, 2019; Revision - December 31, 2019; Accepted - February 15, 2020

Available Online - February 25, 2020

DOI: http://dx.doi.org/10.18006/2020.8(1).35.40

\section{KEYWORDS \\ Callosobruchus maculatus \\ Newer insecticide molecules \\ Spinosad \\ $\mathrm{LC}_{50}$ and $\mathrm{LC}_{99.9}$}

\begin{abstract}
Present study was conducted to evaluate the insecticidal activity and mode of action of commercial formulations of newer insecticides viz., Spinosad $45 \%$ SC, Chlorantraniliprole $18.5 \%$ SC, Emamectin benzoate $5 \%$ SG, Chlorfenapyr $10 \%$ SC against pulse beetle, Callosobruchus maculatus (Fabricius) by dry film residue method under laboratory conditions during the year 2017-18 in the Department of Entomology, Banaras Hindu University. Results of study were compared with check treatment Deltamethrin $2.8 \%$ SC. Among the tested insecticides Spinosad $45 \%$ SC showed best efficacy at both $\mathrm{LC}_{50}$ and $\mathrm{LC}_{99.9}$ and it was more toxicity than other insecticides. The $\mathrm{LC}_{50}$ values of Spinosad $45 \% \mathrm{SC}$ to the adults of $C$. maculatus were $0.0005,0.0003$ and 0.0002 per cent while $\mathrm{LC}_{99.9}$ values were 0.0037 , 0.0027 and 0.001 percent at 24, 48 and 72 hours after treatment (HAT), respectively. The $\log$ concentration probit (lcp) lines slope (b) values for Spinosad $45 \%$ SC were 2.634, 2.513 and 3.455 at 24, 48 and 72 HAT, respectively.
\end{abstract}

* Corresponding author

E-mail: sramesh.babu4@bhu.ac.in (S Ramesh Babu)

Peer review under responsibility of Journal of Experimental Biology and Agricultural Sciences.

Production and Hosting by Horizon Publisher India [HPI] (http://www.horizonpublisherindia.in/).

All rights reserved.
All the articles published by Journal of Experimental Biology and Agricultural Sciences are licensed under a Creative Commons Attribution-NonCommercial 4.0 International License Based on a work at www.jebas.org.

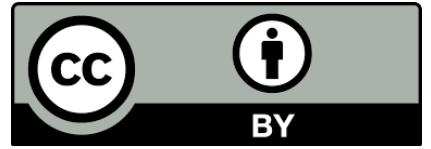




\section{Introduction}

Pulses, the "wonderful gift" of nature, play an important role both as an indispensable constituent of Indian diet and economy. India is the world's largest producer and consumer of pulses, accounting about 25-28\% total global production (Avinash \& Patil 2018). The current per capita supply is $44 \mathrm{~g}$ pulses per day per head and this is lesser than the $105 \mathrm{~g}$ recommended dose of Food and Agriculture Organization (FAO) and World Health Organization (WHO) in a balanced diet (Rawal \& Navarro, 2019). Therefore, for fulfilling the requirement of pulses either the production has to be increased, which seems to be at a slower pace, or can reduce the losses caused by various insect pests and diseases in field and storage coditions. The post-harvest annual losses in pulses due to different insects amount to around 20-25\% (Maneepun, 2003). Decreasing the postharvest losses, particularly in developing countries, could be a sustainable solution for increasing food supply; eliminate hunger and improving the livelihoods of farmers (Kumar \& Kalita, 2017). Pulse beetle is one of the major pests among the storage pests of pulses. Mainly three pulse beetle species viz., Callasobruchus maculatus F., C. analis F. and C. chinensis L. (Chrysomelidae: Coleoptera) have been reported to cause damage to different kinds of pulses in India both in the field and in storage conditions (Ramzan et al., 1986). Use of insecticides to prevent insect infestations has been the main method of grain protection meanwhile it is the simplest and most cost-effective. Insect pests can behave inversely when in contact with pesticides, and these behavioral changes can contribute to their tolerance to pesticides, which can lead to resistance development.

Insect pest tolerance to pesticides is an indicator of the species evolution demonstrating how they can survive and physiologically adapt under chemical stress. Therefore, there is a great need to find alternative or suitable new insecticides molecules which are effective against insecticide-resistant insect species. Most of the latest insecticide groups registered in India in the resent past are safer, highly selective and fit to well in integrated pest management (Hara 2000). Spinosad is presently registered in several countries as a grain protectant at a maximum labeled use rate of $1 \mathrm{ppm}(1 \mathrm{mg}$ a.i./.kg of grain) and with the maximum residue level or tolerance on grains set at 1 or $1.5 \mathrm{ppm}$. Spinosad and emamectin benzoate being derivatives of bacterium can be more practical alternative to the deltamethrin. Both these compounds are highly toxic to bruchids and have relatively low mammalian toxicity. Chlorfenpyr is a natural product isolated from Streptomyces fumanus, it is commercially developed and it has wide range of activities against major pests associated with both in filed and stored products (Satpathy et al., 2005). Chlorantraniliprole is the newly introduced anthranilic diamide has proven to be effective against lepidopteran pests as well as against certain species in the order of Coleoptera, Diptera and Hemiptera (Lahm et al., 2009). Chlorantraniliprole $18.5 \%$ SC was found effective at $\mathrm{LC}_{50}$ level for complete control of Rhizopertha dominica with relative toxicity 2.67 and 4.25 times than malathion and deltamethrin (Ramesh babu et al., 2018). Keeping these facts in mind the present investigation has been undertaken to assess the relative toxicity of newer insecticide molecules having novel mode of action against pulse beetle Callosobruchus maculatus (Fabricius) (Chrysomelidae: Coleoptera) under laboratory conditions.

\section{Material and methods}

\subsection{Rearing of the test insect:}

The initial adult cultures of the test insect, $C$. maculatus were collected from local ware houses/ storage structures and were maintained further in the laboratory on the chickpea for mass rearing. Proceeding to the release, the grains were disinfested by fumigating through aluminium phosphide tablets @ three tablets $(9 \mathrm{~g})$ per tonne for 72 hours and then left in open for 24 hours. A test sample of 250 $\mathrm{g}$ of chickpea was taken in plastic jars $(45 \times 15 \mathrm{~cm})$ and 10 pairs of adults were released for oviposition and the jars were covered with muslin cloth and tightly secured by rubber bands. Mating and oviposition allowed for ten days and then adults were removed. The host grain containing eggs were left undisturbed until the new adults emerge and the subsequent $F_{1}$ progenies from the cultures were used for the further experimental purpose. The mass culture was maintained at a laboratory temperature of $31 \pm 2^{\circ} \mathrm{C}$ and $70 \pm 5 \%$ relative humidity throughout the period of investigation for conducting experiments under laboratory conditions.

\subsection{Test Insecticides}

The formulations of newer insecticides as mentioned below were tested for their toxicity against $C$. maculatus by dry film residue method.

\begin{tabular}{|c|c|c|c|}
\hline \multicolumn{1}{|c}{$\begin{array}{c}\text { S. } \\
\text { No }\end{array}$} & Common Name & \multicolumn{1}{c|}{$\begin{array}{c}\text { Strength of the } \\
\text { insecticide }\end{array}$} & Trade Name \\
\hline 1 & Spinosad & $45 \%$ SC & Tracer \\
\hline 2 & Chlorantraniliprole & $18.5 \%$ SC & Rynaxypyr \\
\hline 3 & $\begin{array}{c}\text { Emamectin } \\
\text { benzoate }\end{array}$ & $5 \%$ SG & Proclaim \\
\hline 4 & $\begin{array}{c}\text { Chlorfenapyr } \\
\text { Deltamethrin } \\
\text { (Check) }\end{array}$ & $2.8 \% \mathrm{EC}$ & Intreprid \\
\hline 5 & \multicolumn{2}{c}{ Decis } \\
\hline
\end{tabular}

\subsection{Bioassay by Dry film residue method:}

The adult beetles of C. maculatus of one week old were subjected to the bioassay with the test insecticides by dry film residue method. In this method $1 \mathrm{ml}$ of different test concentrations of 
insecticide formulations was taken and spread uniformly on the bottom lid of petriplate in a thin layer. The petriplate was allowed to dry at room temperature and then 10 adult insects were released into the petriplate. Similarly the procedure was repeated for all test concentrations and for all insecticides to assess the $\mathrm{LC}_{50}$ value and measure the relative toxicity of the selected insecticides. The test concentrations for each insecticide were selected in such a manner that the per cent mortality varies around $10 \%$ at lower concentration to around $95 \%$ at higher concentration. Mortality was assessed after 24, 48 and 72 hours after treatment and the $\mathrm{LC}_{50}$ values were calculated by probit analysis method (Finney, 1971).

\subsection{Data collection}

The mortality counts of insects in three replications of each concentration were recorded and the average per cent mortality in each concentration was calculated. The per cent mortality in the control, if any, was corrected using Abbot's formula (1925).

Corrected Mortality $(\%)=\frac{\begin{array}{c}\text { Mortality in treatment }(\%)- \\ \text { Mortality in control }(\%)\end{array}}{100 \text {-Mortality in control }(\%)} \times 100$

Relative toxicity of newer insecticides $=\frac{\left.\mathrm{LC}_{50} \text { of deltamethrin }(\text { check })\right)}{\mathrm{LC}_{50} \text { of newer insecticide }}$

\subsection{Statistical Analysis}

Data was analyzed by probit analysis using SPSS v.16.0 software and compute the $\mathrm{LC}_{50}$ and $\mathrm{LC}_{99.9}$ values, heterogeneity $(\chi 2)$, intercept (a), slope of the regression line (b), regression equation and fiducial limits. The $\log$ probit lines were drawn by plotting log concentrations on the $\mathrm{X}$-axis and probits on the $\mathrm{Y}$-axis and therefore the reaction of test insect populations was premeditated at different concentrations of the test insecticides (Finney, 1971).

\section{Results}

3.1. Toxicity of newer insecticide molecules against the pulse beetle, $C$. maculatus

Comparing the toxicity of all insecticides, it was evident that all the test insecticides were variably toxic to pulse beetle, $C$. maculatus adults. The $\mathrm{LC}_{50}$ and $\mathrm{LC}_{99.9}$ values after 24 hours period of exposure revealed that Spinosad $45 \% \mathrm{SC}$ had low $\mathrm{LC}_{50}$ and LC 99.9 values $(0.0005 \%$ and $0.0037 \%)$ followed by Deltamethrin 2.8 $\%$ EC $(0.0036 \%$ and $1.7138 \%)$ and Emamectin benzoate $5 \%$ SG $(0.0044 \%$ and $1.966 \%)$ indicating their higher toxicity (Table 1). The $\mathrm{LC}_{50}$ and $\mathrm{LC}_{99.9}$ values of Chlorantraniliprole $18.5 \% \mathrm{SC}$ and Chlorfenpyr $10 \%$ SC were $(0.0079 \% ; 3.1838 \%)$ and $(0.0195$; 9.5097) respectively that found less toxic.

Even after $48 \mathrm{~h}$ of exposure the $\mathrm{LC}_{50}$ and $\mathrm{LC}_{99.9}$ values revealed that Spinosad $45 \%$ SC had low LC 50 and LC 99.9 values $(0.0003 \%$ and $0.0027 \%)$ followed by Deltamethrin $2.8 \% \mathrm{EC}(0.0010 \%$ and $0.5293 \%)$ and Emamectin benzoate $5 \%$ SG $(0.0013 \%$ and $0.8852 \%$ ) indicating their higher toxicity (Table 2). The $\mathrm{LC}_{50}$ and LC 99.9 values of Chlorantraniliprole $18.5 \%$ SC and Chlorfenpyr 10 $\%$ SC were $0.0037 \% ; 2.5257 \%$ and $0.0085 ; 4.2934$ respectively that were found comparatively less toxic.

After $72 \mathrm{~h}$ exposure, it was evident that all the tested insecticides were toxic to pulse beetle, $C$. maculatus adults. The $\mathrm{LC}_{50}$ and LC 99.9 values after 72 hours period of exposure revealed that Spinosad $45 \%$ SC had lower $\mathrm{LC}_{50}$ and $\mathrm{LC} 99.9$ values $(0.0002 \%$ and 0.001 $\%)$ followed by Deltamethrin $2.8 \%$ EC $(0.0003 \%$ and $0.0288 \%)$ and Emamectin benzoate $5 \%$ SG $(0.0004 \%$ and $0.0365 \%)$ indicating their higher toxicity (Table 3 ). The $\mathrm{LC}_{50}$ and $\mathrm{LC}_{99.9}$ values of Chlorantraniliprole $18.5 \% \mathrm{SC}$ and Chlorfenpyr $10 \% \mathrm{SC}$ were $0.0007 \% ; 0.0377 \%$ and $0.0031 ; 0.4643$ respectively were

Table1 Relative toxicity of selected newer insecticide molecules on the adults of C. maculatus at 24 hours after exposure

\begin{tabular}{|lccccccc|}
\multicolumn{1}{c}{ Insecticides } & $\mathrm{LC}_{50} \%(95 \% \mathrm{FL}) *$ & $\mathrm{LC} 99 \%(95 \% \mathrm{FL}) *$ & Slope b $( \pm \mathrm{SE})$ & $\begin{array}{c}\text { Heterogeneity } \\
(\chi 2)\end{array}$ & $\begin{array}{c}\text { Regression } \\
\text { Equation } \\
(\mathrm{Y}=\mathrm{a}+\mathrm{bx})\end{array}$ & $\begin{array}{c}\text { Relative } \\
\text { toxicity }\end{array}$ & $\begin{array}{c}\text { Order } \\
\text { of } \\
\text { toxicity }\end{array}$ \\
\hline Spinosad 45\% SC & $0.0005(0.0004-0.006)$ & $0.0037(0.0021-0.0103)$ & $2.634( \pm 0.400)$ & 0.233 & $\mathrm{Y}=9.00+2.66 \mathrm{x}$ & 7.20 & 1 \\
\hline Chlorantraniliprole 18.5\%SC & $0.0079(0.0053-0.0147)$ & $3.1838(0.5954-69.5877)$ & $0.892( \pm 0.135)$ & 5.053 & $\mathrm{Y}=2.00+1.00 \mathrm{x}$ & 0.45 & 4 \\
\hline Emamectin Benzoate 5\% SG & $0.0044(0.0028-0.0093)$ & $1.966(0.3315-52.875)$ & $0.877( \pm 0.134)$ & 7.204 & $\mathrm{Y}=2.00+1.00 \mathrm{x}$ & 0.81 & 3 \\
\hline Chlorfenpyr 10\% SC & $0.0195(0.0139-0.0317)$ & $9.5097(1.9583-161.325)$ & $0.865( \pm 0.126)$ & 3.594 & $\mathrm{Y}=1.50+1.00 \mathrm{x}$ & 0.18 & 5 \\
\hline Deltamethrin 2.8\% EC & $0.0036(0.0024-0.0071)$ & $1.7138(0.3003-41.9674)$ & $0.868( \pm 0.131)$ & 4.801 & $\mathrm{Y}=1.40+0.70 \mathrm{x}$ & 1.00 & 2 \\
\hline
\end{tabular}

*The percentage values of $L C_{50}, L C$ 99.9 and Fiducial Limits $(F L)$ of a data set were obtained from mean mortalities of three replications after correction; Lethal concentration and 95\% Fiducial limits (FL) were estimated using probit analysis (SPSS 16.0 v.); The chi-square test revealed the homogeneity of the test population $(p<0.05 \%)$

Journal of Experimental Biology and Agricultural Sciences http://www.jebas.org 
Table 2 Relative toxicity of selected newer insecticide molecules on the adults of $C$. maculatus at 48 hours after exposure

\begin{tabular}{|cccccccc|}
\hline Insecticides & LC50\% (95\% FL) & LC99.9\% (95\% FL) & Slope b $( \pm$ SE) $)$ & $\begin{array}{c}\text { Heterogeneity } \\
(\chi 2)\end{array}$ & $\begin{array}{c}\text { Regression } \\
\text { Equation } \\
(Y=a+b x)\end{array}$ & $\begin{array}{c}\text { Relative } \\
\text { toxicity }\end{array}$ & $\begin{array}{c}\text { Order } \\
\text { of } \\
\text { toxicity }\end{array}$ \\
\hline Spinosad 45 \% SC & $0.0003(0.0003-0.0004)$ & $0.0027(0.0017-0.0065)$ & $2.513( \pm 0.364)$ & 3.290 & Y=9.00+2.66x & 3.33 & 1 \\
\hline Chlorantraniliprole 18.5\%SC & $0.0037(0.0027-0.0058)$ & $2.5257(0.4643-61.3466)$ & $0.821( \pm 0.129)$ & 4.087 & $\mathrm{Y}=2.00+1.00 \mathrm{x}$ & 0.27 & 4 \\
\hline Emamectin Benzoate 5\% SG & $0.0013(0.0009-0.0019)$ & $0.8852(0.1758-16.9375)$ & $0.818( \pm 0.123)$ & 2.108 & $\mathrm{Y}=2.00+1.00 \mathrm{x}$ & 0.76 & 3 \\
\hline Chlorfenpyr 10\% SC & $0.0085(0.0062-0.0118)$ & $4.2934(1.0493-51.8786)$ & $0.860( \pm 0.124)$ & 3.569 & $\mathrm{Y}=1.50+1.00 \mathrm{x}$ & 0.11 & 5 \\
\hline Deltamethrin 2.8\% EC & $0.0010(0.0007-0.0014)$ & $0.5293(0.1318-8.9790)$ & $0.838( \pm 0.123)$ & 2.835 & $\mathrm{Y}=1.40+0.70 \mathrm{x}$ & 1.00 & 2 \\
\hline
\end{tabular}

*The percentage values of $\mathrm{LC}_{50}, \mathrm{LC}_{99.9}$ and Fiducial Limits (FL) of a data set were obtained from mean mortalities of three replications after correction; Lethal concentration and 95\% Fiducial limits (FL) were estimated using probit analysis (SPSS 16.0 v.); The chi-square test revealed the homogeneity of the test population $(\mathrm{p}<0.05 \%)$

Table 3 Relative toxicity of selected newer insecticide molecules on the adults of C. maculatus at 72 hours after exposure

\begin{tabular}{|cccccccc|}
\hline Insecticides & LC50\% (95\% FL) & LC99.9\% (95\% FL) & Slope b $( \pm$ SE) & $\begin{array}{c}\text { Heterogeneity } \\
(\chi 2)\end{array}$ & $\begin{array}{c}\text { Regression } \\
\text { Equation } \\
(\mathrm{Y}=\mathrm{a}+\mathrm{bx})\end{array}$ & $\begin{array}{c}\text { Relative } \\
\text { toxicity }\end{array}$ & $\begin{array}{c}\text { Order } \\
\text { of } \\
\text { toxicity }\end{array}$ \\
\hline Spinosad 45 \% SC & $0.0002(0.0002-0.0002)$ & $0.001(0.0008-0.0014)$ & $3.455( \pm 0.387)$ & 0.586 & $\mathrm{Y}=9.00+2.66 \mathrm{x}$ & 1.50 & 1 \\
\hline Chlorantraniliprole 18.5 \%SC & $0.0007(0.0005-0.0009)$ & $0.0377(0.0206-0.0949)$ & $1.364( \pm 0.151)$ & 5.369 & $\mathrm{Y}=2.00+1.00 \mathrm{x}$ & 0.42 & 4 \\
\hline Emamectin Benzoate 5\% SG & $0.0004(0.0003-0.0005)$ & $0.0365(0.0171-0.1192)$ & $1.182( \pm 0.135)$ & 6.927 & $\mathrm{Y}=2.00+1.00 \mathrm{x}$ & 0.75 & 3 \\
\hline Chlorfenpyr 10\% SC & $0.0031(0.0021-0.0041)$ & $0.4643(0.1952-1.893)$ & $1.067( \pm 0.132)$ & 3.834 & $\mathrm{Y}=1.50+1.00 \mathrm{x}$ & 0.09 & 5 \\
\hline Deltamethrin 2.8\% EC & $0.0003(0.0002-0.0004)$ & $0.0288(0.0134-0.0978)$ & $1.168( \pm 0.141)$ & 8.288 & $\mathrm{Y}=1.40+0.70 \mathrm{x}$ & 1.00 & 2 \\
\hline
\end{tabular}

*The percentage values of $\mathrm{LC}_{50}, \mathrm{LC} \mathrm{C}_{99}$ and Fiducial Limits (FL) of a data set were obtained from mean mortalities of three replications after correction; Lethal concentration and 95\% Fiducial limits (FL) were estimated using probit analysis (SPSS $16.0 \mathrm{v}$.); The chi-square test revealed the homogeneity of the test population $(\mathrm{p}<0.05 \%)$

found comparatively less toxic. The chi-square test values in all insecticides were less than that of table value (12.592) suggesting that the adult population was homogeneous.

With respect to $\mathrm{LC}_{50}$ values, the relative toxicity of these insecticides was arranged in decreasing order: Spinosad $45 \% \mathrm{SC}>$ Deltamethrin $2.8 \%$ EC > Emamectin benzoate $5 \%$ SG > Chlorantraniliprole $18.5 \% \mathrm{SC}>$ Chlorfenpyr $10 \% \mathrm{SC}$ at 24,48 and 72 hours after exposure.

\section{Discussion}

Increase of insecticide resistance in insect pests of stored grains has become a major constraint in grain protection under storage conditions. Due to the resistance by insect pests and negative effects of synthetic conventional insecticides to the environment, it is advisable to use novel and suitable compounds in insect pest management even under storage conditions.

From the above results of present study, it is clearly understood that the Spinosad $45 \%$ SC was found effective at both $\mathrm{LC}_{50}$ and
$\mathrm{LC}_{99.9}$ levels after 24,48 and $72 \mathrm{~h}$ of exposure. The present results are in agreement with the findings of Sanon et al. (2010) who identified the effectiveness of spinosad in controlling C. maculatus which exhibited high mortality and decreased in the number of eggs laid by females. After 6 months of storage, the number of insects emerging from cowpea seeds was reduced by $>80 \%$ by spinosad treatment and around $43 \%$ by coating with deltamethrin. Similarly, Ramesh Babu et al. (2017) reported that the Spinosad $45 \%$ $\mathrm{SC}$ was more toxic to $R$. dominica at $\mathrm{LC}_{50}$ level and showed 1.41 , 1.47 and 1.55 times more toxic than malathion at 24,48 and 72 HAT, respectively. The corresponding value was $1.84,2.02$ and 2.46 times more toxic than deltamethrin at 24,48 and 72 Hours after treatment.

The next best insecticide for management of $C$. maculatus was Deltamethrin $2.8 \% \mathrm{EC}$ showing $\mathrm{LC}_{50}$ and $\mathrm{LC}_{99.9}$ values of 0.0036 and $1.7138 ; 0.0010$ and $0.5293 ; 0.0003$ and 0.0288 percent at 24 , 48 and 72 hours after exposure respectively. The present results are in accordance with the experiments of Srivastava \& Sinha (2008) who studied the susceptibility of pulse beetles $C$. maculatus and $C$. 
analis collected from different centers against the commonly used insecticides malathion, dichlorvos and deltamethrin. All populations showed the highest susceptibility to deltamethrin and least susceptibility to dichlorvos.

The third best insecticide was Emamectin benzoate $5 \%$ SG that showed $\mathrm{LC}_{50}$ and $\mathrm{LC}_{99.9}$ values of 0.0044 and 1.966; 0.0013 and $0.8852 ; 0.0004$ and 0.0365 percent at 24, 48 and 72 hours after exposure respectively. These results were at par with Ghelani et al. (2009) who evaluated some newer insecticidal molecules viz., thiamethoxam (2 ppm), pirimiphos-methyl (4 ppm), emamectin benzoate (4 ppm), spinosad (2 ppm), lufenuron (5 ppm), deltamethin (1 ppm) (standard control) against $R$. dominica and $T$. castaneum to assess the storability of treated pearl millet seed. After 12 months of storage, emamectin benzoate recorded the lowest seed damage $(3.23 \%)$ and while in the untreated seed, it was $18.18 \%$. All the insecticidal seed treatments recorded significantly lower larval and adult population of $R$. dominica and T. castaneum after 12 months of storage.

In the order of toxicity after the emamectin benzoate was Chlorantraniliprole $18.5 \% \mathrm{SC}$ that showed $\mathrm{LC}_{50}$ and $\mathrm{LC}_{99.9}$ values of 0.0079 and $3.1838 ; 0.0037$ and 2.5257; 0.0007 and 0.0377 per cent at 24, 48 and 72 hours after exposure respectively. These results are supported by earlier studies conducted by Ramesh Babu et al. (2018) those who reported that Chlorantraniliprole $18.5 \%$ SC was found more effective at $\mathrm{LC}_{50}$ level for complete control of $R$. dominica with relative toxicity of 2.67 and 4.25 times than malathion and deltamethrin. Chlorfenpyr $10 \%$ SC showed relatively less toxicity compared to other insecticides with $\mathrm{LC}_{50}$ and LC 99.9 values of 0.0195 and $9.5097 ; 0.0085$ and 4.2934; 0.0031 and 0.4643 per cent at 24, 48 and 72 hours after exposure, respectively.

\section{Conclusion}

The present studies revealed that at 24,48 and 72 hours after exposure, relatively more toxic insecticide was Spinosad $45 \%$ SC followed by Deltamethrin $2.8 \% \mathrm{SC}$, Emamectin Benzoate $5 \%$ SC, Chlorantraniliprole $18.5 \%$ SC, Chlorfenpyr $10 \%$ SC respectively. Since there is a chance to develop resistance to deltamethrin due to its constant usage in storage godowns for decreasing the infestation of pulse beetle, there is a need to identify safer seed protectants. Due to the resistance by insect pests and negative effects of synthetic pesticides to the environment, it is essential to use novel and suitable compounds in insect pest management. Both spinosad and emamectin benzoate being derivatives of bacterium can be alternative to the deltamethrin. These compounds are highly toxic to bruchids and have relatively low mammalian toxicity. So, in future these insecticide molecules can be considered as safer alternative to malathion and deltamethrin. Moreover, the susceptibility of an insect species to spinosad varies among different orders or varieties of a commodity. Thus, the concept of combining spinosad with other insecticide molecules needs further evaluation both in terms of efficiency and cost.

\section{Acknowledgement}

The authors are highly thankful to University Grant Commission, New Delhi for providing Fellowship for financial support and Head of Department of Entomology and Agricultural Zoology, Institute of Agricultural Sciences, BHU, Varanasi for providing facilities and support throughout the experimental period.

\section{Conflict of Interest}

Authors would hereby like to declare that there is no conflict of interests that could possibly arise.

\section{References}

Abbots WS (1925) A method of computing the effectiveness of an insecticide. Journal of Economic Entomology 18: 265-267.

Avinash CS, Patil BL (2018) Trends in area, production and productivity of major pulses in Karnataka and India: An economic analysis. Journal of Pharmacognosy and Phytochemistry 7: 20972102.

Finney DJ (1971) Probit analysis. Cambridge University Press, London.109.

Ghelani YH, Dhedhi KK, Joshi HJ, Raghvani KL, Dangaria CJ (2009) Effect of insecticidal seed treatment on viability of pearl millet seed during storage. Karnataka Journal of Agricultural Sciences 22: 633-634.

Hara AH (2000) Finding alternative ways to control alien pests part 2: New insecticides introduced to fight old pests. Hawaii Landscape, $4: 5$.

Kumar D, Kalita P (2017) Reducing postharvest losses during storage of grain crops to strengthen food security in developing countries. Foods 6: 8 .

Lahm, GP, Cordova D, Barry, James D (2009) New and selective ryanodine receptor activators for insect control. Bioorganic and Medicinal Chemistry 17:4127-4133.

Maneepun S (2003) Traditional processing and utilization of legumes. In: Shanmugasundaram S (Ed.), Report of the APO Seminar on Processing and Utilization of Legumes, Japan, 9-14 October 2000. Asian Productivity Organization, Tokyo:53-62. 
Ramesh Babu S, Sai Ram Kumar DV, Madhumathi T (2018) Toxicity of newer insecticide molecules against lesser grain borer, Rhyzopertha dominica (Fabricius) (Bostrichidae: Coleoptera). Journal of Entomology and Zoology Studies 6: 2340-2344.

Ramesh Babu S, Sai Ram Kumar DV, Naga Satya Sri CH, Madhumathi T (2017) Evaluation of Spinosad against Malathion and Deltamethrin Resistant Population of Lesser Grain Borer, Rhyzopertha dominica in Andhra Pradesh, India. International Journal of Current Microbiology and Applied Sciences 6: 165-171.

Ramzan M, Chahal BS, Judge BK (1986) Studies on the preference of pulse beetle, Callosobruchus maculatus F. to some commonly used pulses. Bulletin of Grain Technology 24: 211-214.
Rawal V, Navarro DK, eds. (2019) The Global Economy of Pulses. Rome, FAO Pp:32.

Sanon A, Ba NM, Binso-Dabire CL, Pittendrig BR (2010) Effectiveness of Spinosad (Naturalytes) in Controlling the Cowpea Storage Pest Callosobruchus maculatus (Coleoptera: Bruchidae). Journal of Economic Entomology 103: 203-10.

Satpathy S, Kumar A, Singh, AK, Pandey PK (2005) Chlorfenapyr: A new molecule for diamondback moth (Plutella xylostella L.) management in cabbage. Annals of Plant Protection Sciences 13: 88-90.

Srivastava Chitra, Sinha SN (2008) Susceptibility of Callosobruchus sp. collected from various NSP Centres to insecticides. Annals of Plant Protection Sciences 16: 337-340. 